\title{
Modern pollen distribution of the Teke Peninsula forests: The case of the Ördübek Highland
}

\author{
Çetin Şenkul ${ }^{1 *}$, Nurgül Karlıoğlu Kılıç ${ }^{2}$, Mustafa Doğan ${ }^{1}$, Warren J. Eastwood ${ }^{3}$

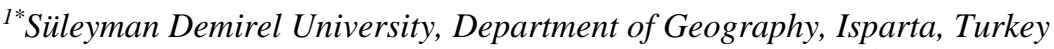

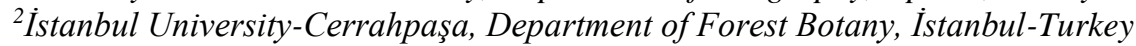 \\ ${ }^{3}$ The University of Birmingham, School of Geography, Birmingham-UK \\ Corresponding author: cetinsenkul@gmail.com
}

\begin{abstract}
This study was carried out in the Teke Peninsula, in Cedrus libani A. Rich. (Lebanon cedar), Juniperus L. sp. (Juniper) and Quercus L. sp. (Oak) mixed forest (Susuz Dağ-Elmal1-Antalya), which is located in the Mediterranean mountain ecosystem. The purpose of the study is to determine the modern pollen distribution (influx and percentage) of this forest and to create a basic calibration scheme for the fossil pollen studies. For the purpose of this study, two-year modern pollen distribution was monitored between the years 2015-2017 using the Tauber pollen traps and moss samples, which were placed at 6 different points in the study area. Furthermore, the surface sediment sample of Lake Avlan was obtained, and the accumulation characteristic of the modern pollen distribution in the lake was revealed. The principles of the European Pollen Monitoring Programme Protocol (EPMPP) were followed in the laboratory methodology. Surface sediment was analyzed according to the classical fossil pollen method. The majority of the pollen influx obtained from the Tauber pollen traps in the Cedrus libani-Juniperus-Quercus forest belongs to arboreal taxa (AP) (Cedrus libani, Pinus L. sp., Quercus coccifera L. and Juniperus sp.). The highest pollen influx of these taxa belongs to Cedrus libani. In the surface sediment sample obtained from Lake Avlan, the highest pollen influx belongs to Pinus sp. When the pollen influx values were compared for the years 2015-2016 and 2016-2017, the pollen influxes of the Tauber pollen traps in all sample areas were higher than the moss samples in 2015-2016 except for the two sample areas (CJQ-1 and CJQ-4). In parallel with the pollen influx in the study area, the majority of the modern pollen percentage distribution (84-94\%) consists of woody taxa. Within these taxa, Cedrus libani, Pinus sp., Quercus coccifera and Juniperus sp. form almost all of the AP percentage.
\end{abstract}

Keywords: European Pollen Monitoring Programme, Cedrus libani, Juniperus, Quercus, Susuz Dağ-Elmalı, Lake Avlan.

\section{Introduction}

The observation of modern ecological processes (modern vegetation distribution, pollen production and distribution, climatic requirements of plants) with the pollen monitoring programmes is the most important point in order to perform paleoecological reconstructions based on the fossil pollen analysis better (Hicks 1986, Eastwood 1997, England 2006, Herzschuh and Birks 2010, Soepboer et al. 2010, Birks 2013, Brewer et al. 2013, Poska 2013, Seppa 2013, Roberts 2014). For this reason, modern data 
sets provide the creation of quantitative interpretation keys in the historical ecology (paleovegetation, palaeoclimate, paleological land use) and restructuring of the historical biodiversity development. However, the use of modern pollen characteristics has been very low in paleoecological reconstructions based on the fossil pollen analysis conducted in Southwestern Anatolia in Turkey (van Zeist et al. 1975, Bottema and Woldring 1984, Eastwood 1997, Sullivan 1989, Vermoere et al. 1999, Vermoere et al. 2002, Müllenhoff et al. 2004, Kaniewski et al. 2007, Bakker et al. 2011, Shumilovskikh et al. 2016).

Therefore, little is known about the distribution characteristics/sedimentation processes of the modern pollen grains in the forest vegetation of Turkey and the demonstration of the modern pollen influxes of the surface sediment samples obtained from the bottoms of the lakes. Furthermore, if no detailed research is done about the modern pollen characteristics in and around the forest vegetation, it is not known to what extent the production, distribution and sedimentation processes of the modern pollen grains are realized and how well they represent the current vegetation at the regional and local scale. In order to fill this gap, the "EPMPP" was created in 1996 and modern pollen-monitoring stations were established in many European countries in the last 22 years. EPMP studies have been started in accordance with this protocol in Turkey in 2011 (Karlığlu 2011, Karlıoğlu and Akkemik 2012, Karlığlu et al. 2014, Karlığlu et al. 2015, Doğan 2017, Şenkul and Doğan 2018, Şenkul et al. 2018a, Şenkul et al. 2018b).

In lake sediments, pollen grains are generally obtained from a larger area compared to traps, moss and soil samples (Wilmshurst and McGlone 2005). Considering from this aspect, various factors such as the size of the lake area (Davis and Brubaker 1973, Sugita 1994), pollen source area (Sugita 1993, Wang et al. 2014), the presence of rivers flowing into/out of the lake, the dominant wind direction over the lake and the sedimentary processes in the lake and the protection of pollen grains (Davis 1968, Davis et al. 1984) affect the distribution and composition of the pollen protected in the lake sediments. In this context, we focused on the reconstruction of the long-term history of paleovegetation, paleological land use, paleoclimate and paleoecological environmental changes in the Teke Peninsula, where the most fossil pollen studies were conducted in Turkey (van Zeist et al. 1975, Bottema and Woldring 1984, Eastwood 1997). However, contrary to the number of fossil pollen studies, there are no data about the modern pollen influxes/percentages in this site.

The purpose of this study is to determine the influx of the modern pollen sedimentation in the forest area and in the lacustrine area near the forest in the formation consisting of Cedrus libani, Quercus sp., and Juniperus sp. taxa in the Ördübek Highland in accordance with the EPMPP. This study will be a basic calibration scheme in order to better interpret the quantitative reconstructions of previous fossil pollen diagrams and future paleovegetation, paleoclimate and paleoecological changes in Southwestern Anatolia.

\section{Material and Methods \\ Study area}

The study area is located in the southern slope of Susuz Dağ, which is between the districts of Finike and Elmalı in Teke region in the southwest of Turkey (Figure 1). The southern border of the area is bounded by the Mediterranean Sea and the northern border by Susuz Dağ (2268 m). The study area, which is called the Ördübek Highland, and its surrounding are located between 1100-1200 meters of the mountainous mass between $0-2300 \mathrm{~m}$. The dominat woody plant species in the area are Cedrus libani, Juniperus excelsa M. Bieb., Juniperus foetidissima Willd., Juniperus oxycedrus L., Quercus 
coccifera, Hippocrepis emerus (L.) Lassen, Lonicera L. sp., Styrax officinalis L., and Cotinus coggygria Scop (Figure 2).

Climatic conditions are the leading factors that determine the distribution and characteristics of vegetation in the study area and its surrounding. The nearest meteorological stations are took place in Elmal1 and Finike district centers. According to the data of the Finike Meteorology Station (19602015), the average annual precipitation is $961.4 \mathrm{~mm}$, and the average temperature is $18.9{ }^{\circ} \mathrm{C}$. According to the data of the Elmalı Meteorology Station (1958-2015), the average annual precipitation is $461.3 \mathrm{~mm}$, and the average temperature is $12.9{ }^{\circ} \mathrm{C}$ (Table 1). Climatic factors such as elevation, aspect, distance from the sea and direction of mountains, temperature, precipitation, and wind vary within short distances within the study area. Under these conditions, the southward slopes of the mountains in the coastal area receive annual precipitation over $1000 \mathrm{~mm}$.

Table 1. Long-year average temperature, humidity, and precipitation of the Elmalı and Finike stations (General Directorate of Meteorology).

\begin{tabular}{|c|c|c|c|c|c|c|c|c|c|c|c|c|c|}
\hline $\begin{array}{c}\text { EImalı }(1095 \text { m) } \\
(1958-2015) \\
\end{array}$ & $\mathbf{J}$ & $\mathbf{F}$ & $\mathbf{M}$ & $\mathbf{A}$ & $\mathbf{M}$ & $\mathbf{J}$ & $\mathbf{J}$ & $\mathbf{A}$ & $\mathbf{S}$ & $\mathbf{O}$ & $\mathbf{N}$ & D & Year \\
\hline $\begin{array}{c}\text { Average temperature } \\
\left({ }^{\circ} \mathrm{C}\right) \\
\text { Average Humidity }\end{array}$ & 2.4 & 3.3 & 6.9 & 11.3 & 16.1 & 20.9 & 24.3 & 24.1 & 19.9 & 14.2 & 8.6 & 4.1 & 13 \\
\hline$(\%)$ & 71 & 67.5 & 60.5 & 54.6 & 52.2 & 44.8 & 39.2 & 39.9 & 44.6 & 55.1 & 64 & 71.9 & 55.4 \\
\hline $\begin{array}{c}\text { Precipitation }(\mathrm{mm}) \\
\text { Finike }(3 \mathrm{~m}) \\
(1960-2015) \\
\end{array}$ & 82.3 & 59.4 & 47.6 & 32.1 & 28 & 21.2 & 10.1 & 8 & 7.6 & 32.9 & 46.6 & 85.5 & 461.3 \\
\hline $\begin{array}{c}\text { Average temperature } \\
\left({ }^{\circ} \mathrm{C}\right) \\
\text { Average Humidity }\end{array}$ & 11.1 & 11.4 & 13.3 & 16.5 & 20.7 & 25.2 & 28.0 & 27.8 & 24.4 & 20 & 15.7 & 12.5 & 18.9 \\
\hline$(\%)$ & 69.6 & 69.8 & 69.9 & 68.8 & 68.5 & 62.6 & 61.2 & 62.5 & 63.9 & 66.5 & 68 & 69.8 & 66.8 \\
\hline Precipitation $(\mathrm{mm})$ & 223.7 & 149.8 & 85.3 & 45.2 & 20.1 & 8.3 & 2.2 & 1.3 & 11.3 & 64.9 & 120 & 229.3 & 961.4 \\
\hline
\end{tabular}

\section{Pollen Analyses}

\section{Modern pollen data from the Tauber pollen traps}

In order to obtain modern pollen data, 6 Tauber pollen traps (Tauber 1974, Hicks and Hyvärinen 1986) were placed in the study area in 2015, and in the following year, traps were taken from the land, and new traps were placed in their place. Table 2 shows the codes, coordinates, elevation, vegetation and common plant species around the Tauber pollen traps.

Table 2. Location and vegetation information of the pollen traps and moss samples.

\begin{tabular}{|c|c|c|c|c|c|c|}
\hline $\begin{array}{c}\text { Pollen trap } \\
\text { code }\end{array}$ & $\begin{array}{c}\text { Moss sample } \\
\text { code }\end{array}$ & Latitude & Longitude & $\begin{array}{c}\text { Elevation } \\
(\mathbf{m})\end{array}$ & $\begin{array}{c}\text { Type of } \\
\text { vegetation }\end{array}$ & $\begin{array}{c}\text { Common } \\
\text { species }\end{array}$ \\
\hline CJQ-1-T & CJQ-1-M & $36^{\circ} 31^{\prime} 24.50^{\prime \prime} \mathrm{N}$ & $29^{\circ} 58^{\prime} 38.12^{\prime \prime E}$ & 1340 & Forest & Cedrus \\
\hline CJQ-2-T & CJQ-2-M & $36^{\circ} 31^{\prime} 24.20^{\prime \prime} \mathrm{N}$ & $29^{\circ} 58^{\prime} 40.09^{\prime \prime} \mathrm{E}$ & 1334 & Forest & libani, \\
\hline CJQ-3-T & CJQ-3-M & $36^{\circ} 31^{\prime} 25.65^{\prime \prime} \mathrm{N}$ & $29^{\circ} 58^{\prime} 14.533^{\prime \prime} \mathrm{E}$ & 1392 & Forest & Juniperus \\
\hline CJQ-4-T & CJQ-4-M & $36^{\circ} 31^{\prime} 25.08^{\prime \prime} \mathrm{N}$ & $29^{\circ} 58^{\prime} 13.08^{\prime \prime} \mathrm{E}$ & 1392 & Forest & excelsa, \\
\hline CJQ-5-T & CJQ-5-M & $36^{\circ} 31^{\prime} 22.11^{\prime \prime} \mathrm{N}$ & $29^{\circ} 58^{\prime} 8.89^{\prime \prime} \mathrm{E}$ & 1388 & Forest & \\
\hline CJQ-6-T & CJQ-6-M & $36^{\circ} 31^{\prime} 21.84^{\prime \prime} \mathrm{N}$ & $29^{\circ} 58^{\prime} 10.36^{\prime \prime} \mathrm{E}$ & 1382 & Forest & $\begin{array}{c}\text { foetıdissima, } \\
\text { Juniperus } \\
\text { oxycedrus, } \\
\text { Quercus } \\
\text { coccifera }\end{array}$ \\
\hline
\end{tabular}




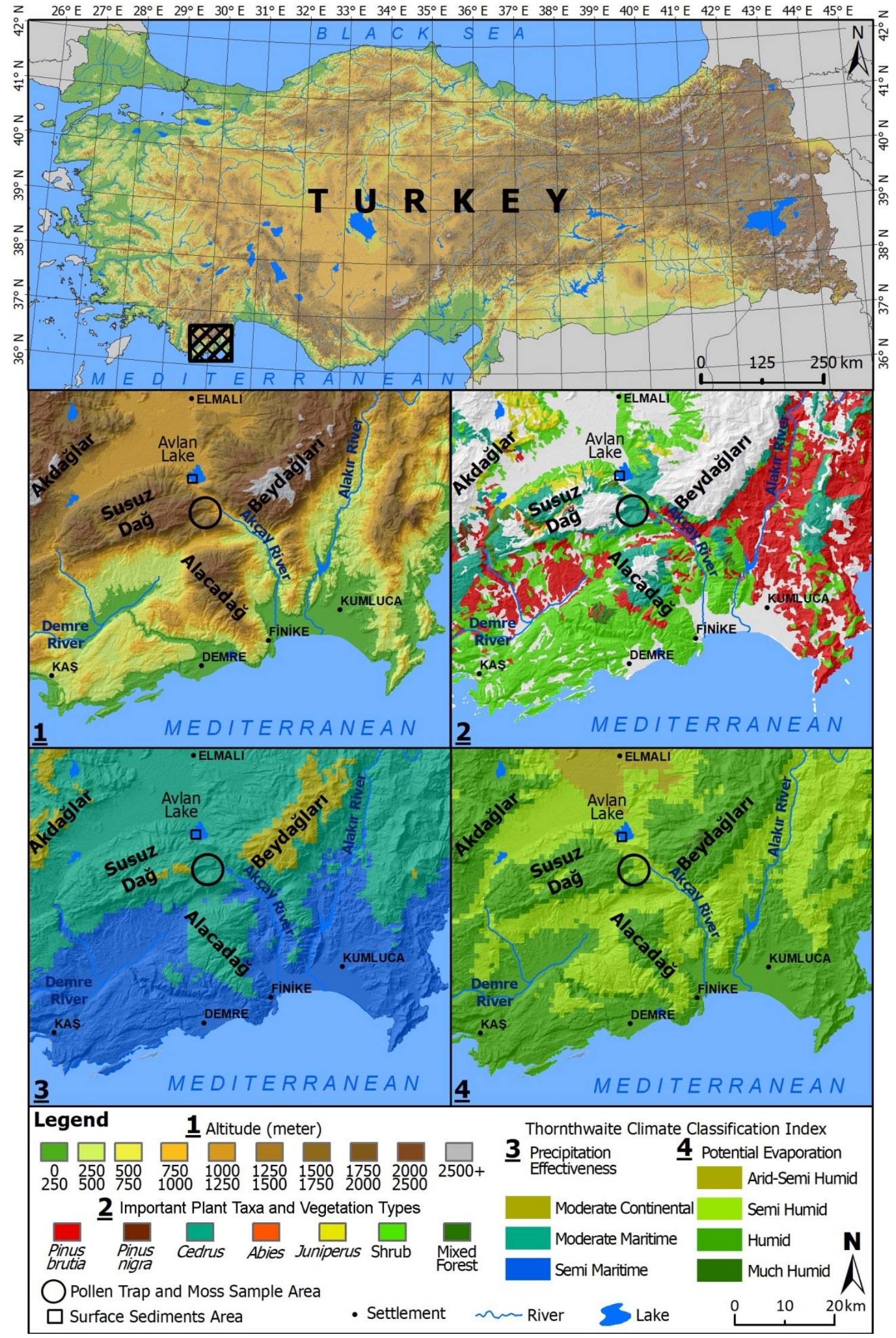

Figure 1. Location map of the study area.

(1. Altitude, 2. Important plant taxa and vegetation types, 3. Precipitation effectiveness, 4. Potential evaporation) 


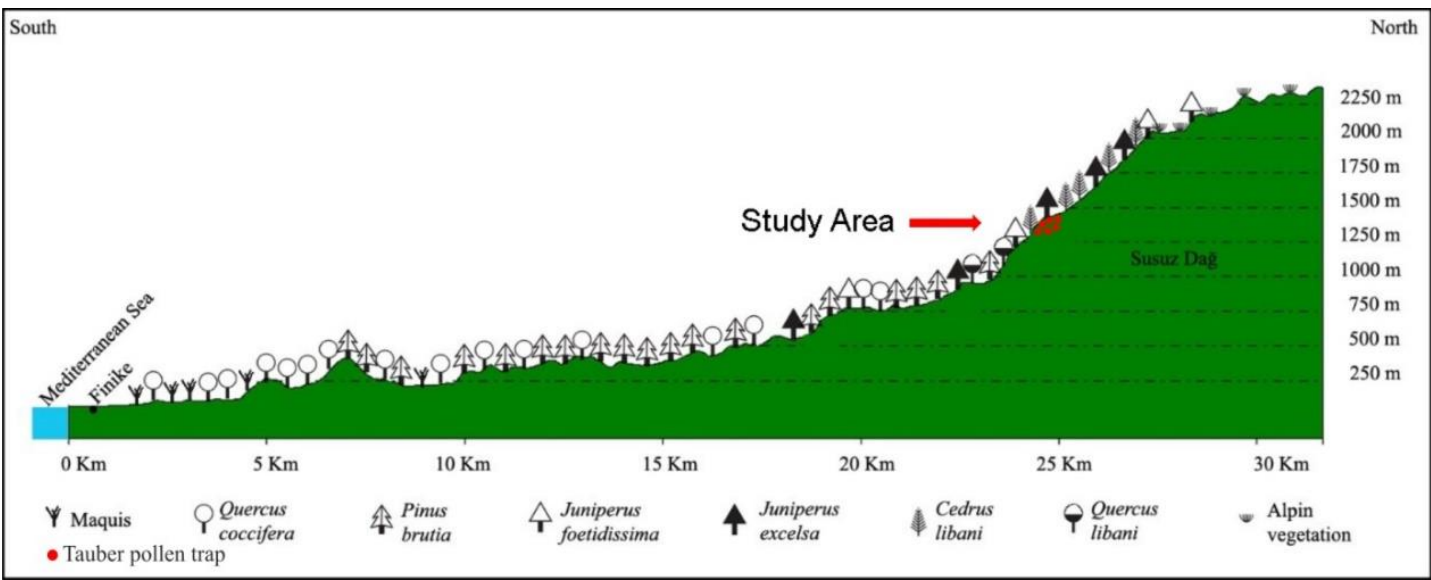

Figure 2. Mediterranean Sea-Susuz Dağ section and location of the Tauber pollen traps in the study area.

In the laboratory methodology applied to the Tauber pollen traps collected from the field, the principles of the EPMPP were followed. According to this protocol, the liquid in the Tauber pollen traps was filtered through a $180 \mathrm{~m} \mu$ sieve. Lycopodium spore tablets dissolved in $10 \% \mathrm{HCl}$ were added to the filtered liquid. The mixture of Lycopodium spore tablets dissolved with the liquid obtained from the traps was reduced to a single tube by centrifugation (for 5 minutes at $4000 \mathrm{rpm}$ ). Hot Potassium Hydroxide (10\% KOH), Glacial Acetic Acid and acetolysis were applied to the remaining liquid in the single tube. After chemical procedures, the pollen grains in the tube were prepared using silicone oil (Hicks et al. 1996). Pollen counting and identification of pollen preparations were carried out with a computer-aided Leica DM750 branded light microscope, using x40 and x100 immersion lenses and 10x ocular lens. For pollen identification, the reference pollen preparations, pollen atlases (Moore et al. 1991, Reille 1995, Reille 1998, Reille 1999) were used, and PalDat (https://www.paldat.org) and Pollen info (https://www.polleninfo.org) websites were used. For each sample area, it was ensured that the counted land pollen (non-aquatic) was at least 200 (Hicks et al. 1996). The pollen influx per unit area of each taxon belonging to the samples was calculated and diagrammed using the Tilia 2.0.41 program (Grimm 2015).

\section{Modern pollen data from the moss samples}

A total of 6 moss samples were taken from the surrounding of the pollen traps placed at the points determined in the field. The principles of the EPMPP were followed in the laboratory methodology applied to moss samples obtained as a result of field studies. According to the protocol applied, Potassium Hydroxide $(10 \% \mathrm{KOH})$ was added to the moss samples, and the samples were kept in a hot water bath, respectively. The moss samples taken from the water bath were filtered through a $180 \mathrm{m \mu}$ sieve, and the Lycopodium spore tablet was added to the filtered sample. The pollen liquid of the moss samples was reduced to a single tube by centrifugation (for 5 minutes at $4000 \mathrm{rpm}$ ). In the analysis of the Tauber pollen traps (procedures applied after reducing to a single tube), the procedures applied in the counting and the obtainment of diagrams were applied to the sample reduced to a single tube.

\section{Modern pollen data from the surface sediment}

Furthermore, a surface sediment sample was taken from Lake Avlan in 2017 with the Glew Corer sampler (Glew 1995), and the first $2 \mathrm{~cm}$ section of this sample was analyzed according to the classical fossil pollen method (Faegri and Iversen 1975, Moore et al. 1991). 


\section{Determination of plants around the pollen traps}

Field studies were conducted between March and September in the years 2015-2017 in order to determine plant taxa around the pollen traps. In the study area, the principles of the EPMPP (Hicks et al. 1996) were applied to determine plant species around 0-10.5 $\mathrm{m}$ of each pollen trap within the forest area. According to these principles, the plant species in the 0-0.5 m, 0.5-1.5 m, 1.5-2.5 m, 2.5-3.5 m, 3.5-4.5 m, 4.5-5.5 m, 5.5-6.5 m, 6.5-7.5 m, 7.5-8.5 m, 8.5-9.5 m, 9.5-10.5 m circular area around the traps were identified and listed (Hicks et al. 1996).

\section{Results}

\section{Pollen Influx from the Tauber Pollen Traps}

According to the annual pollen influx data obtained from the CJQ-1-T sample area in Susuz DağFinike for 2015-2016, the highest pollen influx belongs to Cedrus libani among the woody species with $4183 \mathrm{~cm}^{2} /$ year. Cedrus libani is followed by Pinus sp. with $1701 \mathrm{~cm}^{2} /$ year and Juniperus sp. with $1339 \mathrm{~cm}^{2} /$ year, respectively. On the other hand, the pollen influx of herbaceous plants is very low (the most significant herbaceous plant pollen influx belongs to Euphorbia L. sp. with $251 \mathrm{~cm}^{2} /$ year). In the CJQ-2-T sample area, the highest pollen influx belongs to the same woody and herbaceous taxa, but the annual pollen influxes are higher compared to the CJQ-1-T location. In the CJQ-3-T, the annual pollen influxes of Cedrus libani, Pinus sp., Juniperus sp. among the woody taxa were determined to be highest at this location among all sample areas. The annual pollen influx data of CJQ-4-T, CJQ-5T, and CJQ-6-T among the sample areas belong to the same woody and herbaceous taxa. On the other hand, Quercus coccifera showed the highest pollen influx in this sample area only at the CJQ-5-T location with $1886 \mathrm{~cm}^{2} /$ year (Figure 3). When the total annual pollen influxes among all sample areas were compared for the years 2015-2016, the highest annual pollen influx was determined in the CJQ3-T sample area with $19949 \mathrm{~cm}^{2} /$ year. The lowest annual pollen influx is in the CJQ-1-T with 8478 $\mathrm{cm}^{2} /$ year. In all sample areas, the influx of herbaceous species in the CJQ-1-T sample area is quite low. At the CJQ-T location, the majority of the total pollen influx of the sample areas belongs to woody species (Cedrus libani, Pinus sp., Juniperus sp.). In the herbaceous species, the highest influx belongs to Euphorbia sp. in all sample areas (Figure 3).

In the years of 2016-2017, the highest pollen influx in the CJQ-1-T sample area belongs to woody species again (Cedrus libani, $4410 \mathrm{~cm}^{2} /$ year; Pinus sp., $1440 \mathrm{~cm} /$ year; Quercus coccifera, 776 $\mathrm{cm}^{2} /$ year). The most important herbaceous plant pollen influx in the area belongs to Euphorbia sp. again with $488 \mathrm{~cm}^{2} /$ year. No data could be provided for this location due to the damaged pollen trap placed in the CJQ-2-T sample area. In the CJQ-3-T, Cedrus libani has the highest pollen influx with $4916 \mathrm{~cm}^{2} /$ year. Cedrus libani is followed by Pinus sp. (2396 cm $\left.2 / y e a r\right)$ and Juniperus sp. (2107 $\mathrm{cm}^{2} /$ year), respectively. The most significant herbaceous plant pollen influx in the area belongs to Euphorbia sp. again (269 $\mathrm{cm}^{2} /$ year) (Figure 3). At the CJQ-4-T, CJQ-5-T, and CJQ-6-T locations among the sample areas, the highest pollen influx for the years 2016-2017 belongs to the same woody taxa. At the CJQ-4-T and CJQ-6-T among these sample areas, the highest pollen influx of herbaceous plants belongs to the same species (Euphorbia sp.). In CJQ-5-T, herbaceous plants with a high pollen influx vary, while the highest influx belongs to the families of Caryophyllaceae and Poaceae (Figure 3).

When the total annual pollen influxes at the location of Cedrus libani-Juniperus-Quercus (CJQ-T) in Susuz Dağ-Finike were compared among all samples areas for the years 2016-2017, the highest pollen influx was determined in the CJQ-6-T sample area with $21706 \mathrm{~cm}^{2} /$ year. The lowest total annual pollen influx was determined in the CJQ-1-T sample area with $8659 \mathrm{~cm}^{2} /$ year. At the CJQ-T location, the majority of the total pollen influx of the sample areas belongs to woody species (Cedrus libani, Pinus sp., Juniperus sp.). In the herbaceous species, the highest influx belongs to Euphorbia sp. except for the CJQ-5-T sample area (Figure 3). 


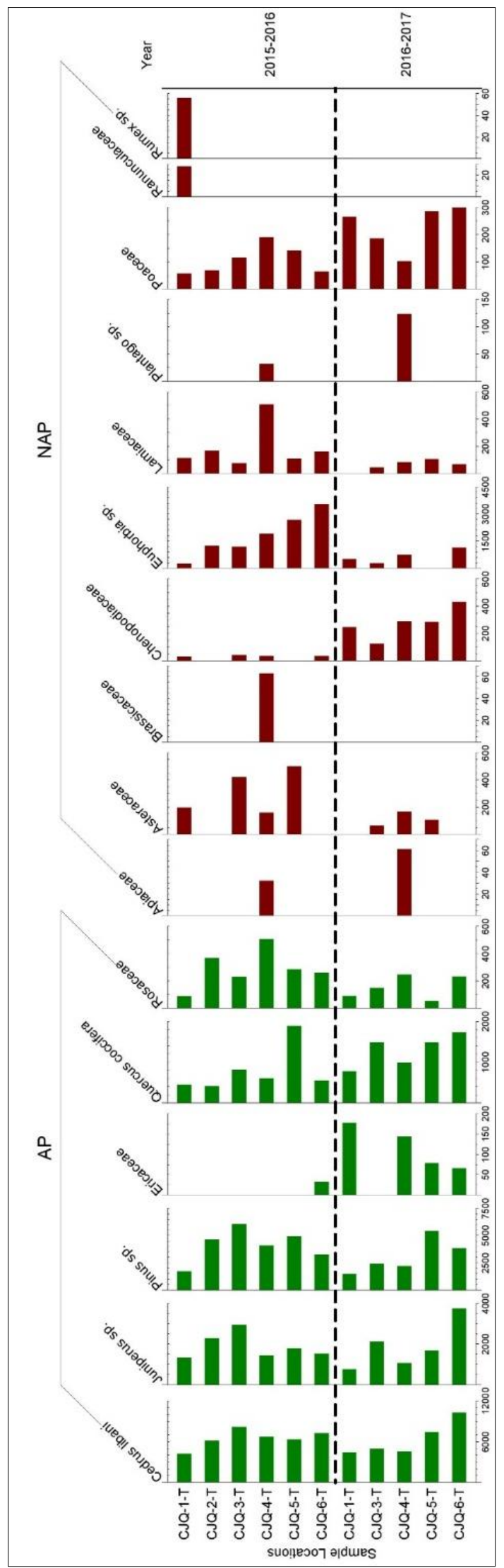

Figure 3. Pollen influx obtained from the Tauber pollen traps between 2015-2017 at the location of Cedrus libani -Juniperus sp.-Quercus sp. (CJQ). 


\section{Pollen Influx from the Mosses}

In 2015-2016, the highest pollen influx in the CJQ-1-Y sample area belongs to Cedrus libani (2114 $\mathrm{cm}^{2} /$ year) and Pinus sp. (1705 $\mathrm{cm}^{2} /$ year) among the woody species. The herbaceous plant influx in the area is quite low compared to the woody plant influx. In the CJQ-2-Y and CJQ-3-Y sample areas, the highest pollen influx belongs to Cedrus libani among woody species, followed by Pinus sp. (Figure 4). In the CJQ-4-Y, CJQ-5-Y, and CJQ-6-Y sample areas, the highest pollen influx belongs to woody species (Cedrus libani, $3787 \mathrm{~cm}^{2} /$ year; Pinus sp., $2702 \mathrm{~cm}^{2} /$ year; Quercus coccifera, $1404 \mathrm{~cm}^{2} /$ year). The most significant herbaceous plant pollen influx in these sample areas belongs to the Asteraceae family and Euphorbia sp. (Figure 4).

When woody plant influx data in all sample areas are compared for 2015-2016, the highest pollen influx belongs to Cedrus libani, Pinus sp., and Quercus coccifera. Although the herbaceous plant pollen influxes in these sample areas are very low, Asteraceae influx stands out (Figure 4).

In 2016-2017, the highest pollen influx in the CJQ-1-Y sample area belongs to woody species (Cedrus libani, $6843 \mathrm{~cm}^{2} /$ year; Pinus sp., $1798 \mathrm{~cm}^{2} /$ year). The herbaceous plant influx is quite low in the area, and the highest influx belongs to Asteraceae with $241 \mathrm{~cm}^{2} /$ year. The moss sample of the CJQ-2-Y could not be analyzed due to the damaged trap in this area. In the CJQ-3-Y, the highest pollen influx belongs to woody species (Cedrus libani, $4417 \mathrm{~cm}^{2} /$ year; Pinus sp., $1434 \mathrm{~cm}^{2} /$ year, Quercus coccifera, $994 \mathrm{~cm}^{2} /$ year). The herbaceous plant pollen influx is quite low. In the CJQ-4-Y sample area, the highest pollen influx belongs to woody species (Cedrus libani, $4964 \mathrm{~cm}^{2} /$ year; Quercus coccifera, $2188 \mathrm{~cm}^{2} /$ year). The highest herbaceous plant influx belongs to Euphorbia sp. (709 $\mathrm{cm}^{2} /$ year). In the CJQ-5-Y, the highest pollen influx belongs to woody species (Cedrus libani, 4374 $\mathrm{cm}^{2} /$ year; Quercus coccifera, $1133 \mathrm{~cm}^{2} /$ year; Pinus sp., $775 \mathrm{~cm}^{2} /$ year). The herbaceous plant pollen influx is low, and the highest influx belongs to Asteraceae with $278 \mathrm{~cm}^{2} /$ year, and Poaceae with 119 $\mathrm{cm}^{2} /$ year. In the CJQ-6-Y sample area, the highest pollen influx belongs to woody species (Cedrus libani, $3538 \mathrm{~cm} /$ year; Quercus coccifera, $1321 \mathrm{~cm}^{2} /$ year; Pinus sp., $1142 \mathrm{~cm}^{2} / \mathrm{year}$ ). The highest herbaceous plant pollen influx belongs to Asteraceae with $470 \mathrm{~cm}^{2} / y e a r$, Apiaceae and Poaceae taxa with $112 \mathrm{~cm}^{2} /$ year (Figure 4).

When woody plant influx data in all sample areas are compared for 2016-2017, the highest pollen influx belongs to Cedrus libani, Pinus sp., and Quercus coccifera, while an increase is observed in the influx of Juniperus sp. compared to 2015-2016. The herbaceous plant pollen influxes in these sample areas have increased, and the highest pollen influx belongs to Asteraceae, Euphorbia sp. and Poaceae (Figure 4).

\section{Pollen Influx from the Surface Sediment}

In the pollen analysis of the surface sediment taken from Lake Avlan, the annual woody plant pollen influx is $25280 \mathrm{~cm}^{2} /$ year. Pinus sp. (15535 $\mathrm{cm}^{2} /$ year) is in the first place in this pollen influx, followed by Cedrus libani (7051 cm²/year), Abies Mill. sp. (917 cm²/year), Castanea sativa Mill. (516 $\mathrm{cm}^{2} /$ year), Quercus cerris type (a group of deciduous oaks) $\left(401 \mathrm{~cm}^{2} /\right.$ year), Olea europaea $\mathrm{L}$. and Ephedra L. sp., respectively. Other important woody taxa, which have a small amount of pollen influx, include Alnus Mill. sp., Ostrya carpinifolia Scop., and Salix L. sp. In the pollen analysis of the surface sediment taken from Lake Avlan, the annual herbaceous plant pollen influx is $3382 \mathrm{~cm}^{2} / y e a r$. The highest pollen influx belongs to Ranunculus L. sp. (1318 cm²/year), followed by Anthemis type (343 $\mathrm{cm}^{2} /$ year). Other important herbaceous plant taxa, which have a small amount of pollen influx, are Brassicaceae, Caryophyllaceae, Artemisia L. sp., Chenopodiaceae, Plantago lanceolata L., and Poaceae (Figure 5). 


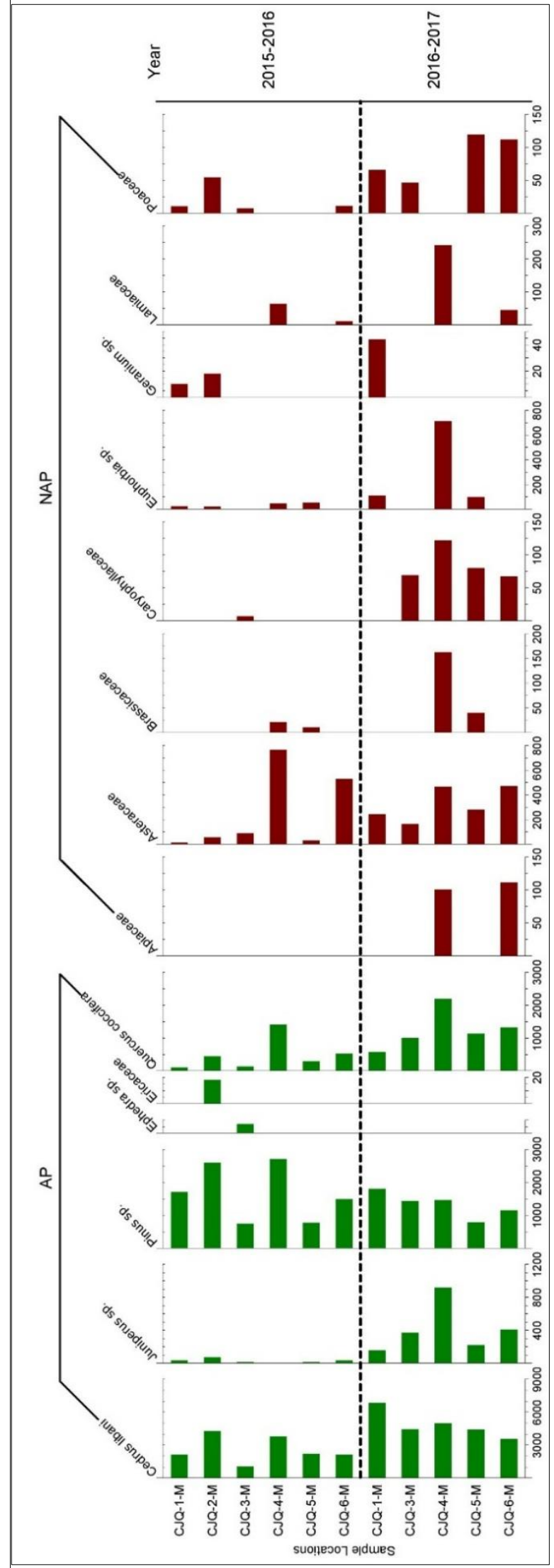

Figure 4. Pollen influx obtained from the moss samples between 2015-2017 at the location of Cedrus libaniJuniperus sp.-Quercus sp. (CJQ). 


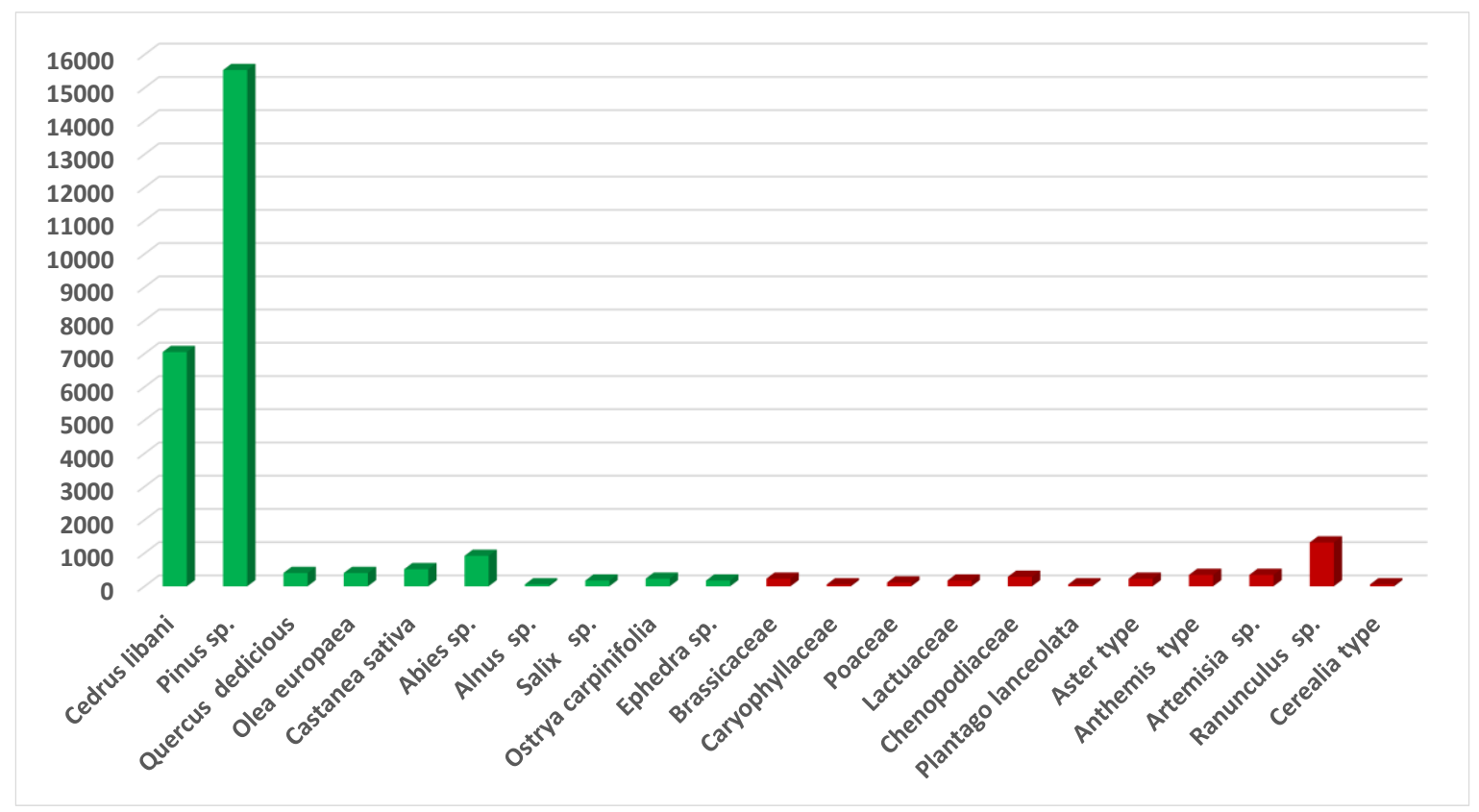

Figure 5. Pollen influx obtained from the surface sediment of Lake Avlan for 2017.

\section{Findings of plant taxa}

The woody species around the traps are composed of Cedrus libani, Juniperus excelsa, Juniperus foetidissima, Juniperus oxycedrus, Quercus coccifera, Hippocrepis emerus, Lonicera sp., Styrax officinalis, and Cotinus coggygria. In the pollen analysis, Pinus sp., which has a high and significant concentration, was not found around the traps. The herbaceous species vary in the sample areas because of the canopy cover of the woody species. Among the herbaceous species, Vinca L. sp., Geranium L. sp., Salvia tomentosa Mill., and Lapsana L. sp. are common species around the traps (Table 3).

Table 3. Plant taxa around the pollen traps.

\begin{tabular}{|c|c|c|c|}
\hline \multirow{2}{*}{$\begin{array}{l}\text { Distance } \\
\text { to Pollen } \\
\text { Trap } \\
\end{array}$} & \multicolumn{3}{|c|}{ Sample Received } \\
\hline & CJQ-1-T & CJQ-2-T & CJQ-3-T \\
\hline $0-0.5 \mathrm{~m}$ & & & $\begin{array}{l}\text { Vinca sp., Scorzonera (L.) sp., } \\
\text { Ornithogalum (L.) sp., }\end{array}$ \\
\hline $0.5-1.5 \mathrm{~m}$ & $\begin{array}{l}\text { Veronica (L.) sp., } \\
\operatorname{Geranium}(\text { L.) sp. }\end{array}$ & Cedrus libani & Ornithogalum sp., Silene italica \\
\hline $1.5-2.5 \mathrm{~m}$ & $\begin{array}{l}\text { Juniperus excelsa, } \\
\text { Veronica sp., Geranium sp. }\end{array}$ & Juniperus excelsa & $\begin{array}{c}\text { Styrax officinalis, Ornithogalum sp., } \\
\text { Salvia tomentosa }\end{array}$ \\
\hline $2.5-3.5 \mathrm{~m}$ & $\begin{array}{l}\text { Cedrus libani, Juniperus } \\
\text { excelsa, Geranium sp. }\end{array}$ & $\begin{array}{l}\text { Juniperus excelsa, } \\
\text { Juniperus oxycedrus }\end{array}$ & $\begin{array}{c}\text { Quercus coccifera, Lonicera sp., } \\
\text { Ornithogalum sp. }\end{array}$ \\
\hline $3.5-4.5 \mathrm{~m}$ & $\begin{array}{l}\text { Cerastium (L.) sp., } \\
\text { Lonicera (L.) sp., } \\
\quad \text { Geranium sp. }\end{array}$ & $\begin{array}{l}\text { Juniperus excelsa, } \\
\text { Juniperus oxycedrus, } \\
\text { Salvia sp. }\end{array}$ & $\begin{array}{l}\text { Cedrus libani, Quercus coccifera, } \\
\text { Juniperus foetidissima, Lapsana sp. }\end{array}$ \\
\hline $4.5-5.5 \mathrm{~m}$ & $\begin{array}{l}\text { Juniperus excelsa, } \\
\text { Juniperus oxycedrus }\end{array}$ & $\begin{array}{l}\text { Cedrus libani, } \\
\text { Juniperus oxycedrus, } \\
\text { Anthemis sp. }\end{array}$ & $\begin{array}{c}\text { Vinca sp., Ornithogalum sp., Silene } \\
\text { italica, Salvia tomentosa, Astragalus (L.) } \\
\text { sp. }\end{array}$ \\
\hline $5.5-6.5 \mathrm{~m}$ & $\begin{array}{l}\text { Juniperus oxycedrus, } \\
\text { Geranium } \mathrm{sp} . \\
\text { Vinca }(\text { L.) } \mathrm{sp} .\end{array}$ & $\begin{array}{l}\text { Cedrus libani, } \\
\text { Salvia sp. }\end{array}$ & $\begin{array}{l}\text { Quercus coccifera, Juniperus excelsa, } \\
\text { Juniperus oxycedrus, Geranium sp., } \\
\text { Saponaria (L.) sp. }\end{array}$ \\
\hline $6.5-7.5 \mathrm{~m}$ & $\begin{array}{l}\text { Juniperus foetidissima, } \\
\text { Juniperus excelsa, } \\
\text { Juniperus oxycedrus, } \\
\text { Cerastium sp., Geranium sp. }\end{array}$ & $\begin{array}{l}\text { Cedrus libani, } \\
\text { Anthemis sp., } \\
\text { Phlomis grandiflora } \\
\text { H.S. Thompson }\end{array}$ & $\begin{array}{c}\text { Juniperus foetidissima, } \\
\text { Salvia tomentosa, Saponaria sp., } \\
\text { Briza }(\text { L.) sp., } \\
\text { Alyssum }(\mathrm{L} .) \text { sp. }\end{array}$ \\
\hline
\end{tabular}


7.5-8.5 m

$9.5-10.5 \mathrm{~m}$

Cedrus libani, Juniperus foetidissima, Juniperus excelsa, Juniperus oxycedrus, Quercus coccifera,

Cerastium sp., Geranium sp., Lamium (L.) sp.,

Salvia (L.) sp., Anthemis (L.) sp.

Cedrus libani, Juniperus foetidissima, Juniperus oxycedrus, Hippocrepis emerus, Lonicera sp.,

Lamium sp., Anthemis sp.

Cedrus libani, Juniperus excelsa, Juniperus oxycedrus, Hippocrepis emerus, Cerastium sp., Lonicera sp., Vinca sp., Lamium sp.
Cedrus libani, Juniperus excelsa, Juniperus oxycedrus, Quercus coccifera, Hippocrepis emerus,

Salvia sp., Phlomis grandiflora, Silene italica

(L.) Pers., Lamium sp.

Cedrus libani, Juniperus foetidissima, Silene italica, Lamium sp.

Cedrus libani, Juniperus foetidissima, Juniperus oxycedrus, Silene italica
Cedrus libani, Quercus coccifera, Juniperus excelsa, Juniperus foetidissima, Vinca sp., Ornithogalum sp., Silene italica, Lapsana sp., Geranium sp., Saponaria sp., Alyssum sp., Lapsana communis L., Lamium sp.

Brachypodium (L.) sp., Ajuga (L.) sp. Cerastium sp., Anthemis rosea Sm., Erysimum (L.) sp.

Cedrus libani, Quercus coccifera, Juniperus foetidissima, Lonicera sp.,

Ornithogalum sp., Lapsana sp.,

Geranium sp., Briza sp., Lapsana communis, Lamium sp., Cerastium sp. Quercus coccifera, Juniperus excelsa, Vinca sp., Lapsana sp.,

Lapsana communis, Lamium sp., Ajuga sp.

Lamium $\mathrm{sp.}$
CJQ-4-T

$\begin{array}{cc}0-0.5 \mathrm{~m} & \begin{array}{c}\text { Vinca } \mathrm{sp} ., \text { Scorzonera } \mathrm{sp} . \\ \text { Ornithogalum } \mathrm{sp} . \\ \text { Scorzonera } \mathrm{sp} .\end{array} \\ 0.5-1.5 \mathrm{~m} & \begin{array}{c}\text { Ornithogalum } \mathrm{sp} . \\ \text { Styrax officinalis, }\end{array} \\ 1.5-2.5 \mathrm{~m} & \begin{array}{c}\text { Ornithogalum } \mathrm{sp}, \\ \text { Salvia tomentosa }\end{array}\end{array}$

Quercus coccifera,

2.5-3.5 m Juniperus foetidissima, Lonicera sp., Ornithogalum sp.

Cedrus libani, Quercus coccifera, Juniperus foetidissima,

$3.5-4.5 \mathrm{~m}$ Juniperus oxycedrus, Lapsana sp.

Juniperus foetidissima, 4.5-5.5 m Vinca sp., Ornithogalum sp., Silene italica, Salvia tomentosa, Astragalus sp. Quercus coccifera,

5.5-6.5 m

Juniperus excelsa, Geranium sp., Saponaria sp.

Salvia tomentosa, Geranium sp., Saponaria sp., Briza sp.

Quercus coccifera, Juniperus excelsa, Juniperus foetidissima,

7.5-8.5 m
Juniperus oxycedrus, Vinca sp., Ornithogalum sp., Silene italica, Lapsana sp., Geranium sp., Saponaria sp., Alyssum sp., Lapsana communis, Lamium sp.,

\section{CJQ-5-T}

\section{CJQ-6-T}

\section{Brachypodium sp.} Geranium sp.

Quercus coccifera,

Geranium sp., Briza sp., Lapsana sp. Cedrus libani,

Juniperus foetidissima, Valeriana (L.) sp., Lamium sp.

Juniperus excelsa, Juniperus foetidissima, Brachypodium sp.,

Geranium sp., Valeriana sp., Ornithogalum sp.

Quercus coccifera, Juniperus excelsa,

Lapsana sp., Lamium sp., Alyssum sp., Aubrieta pinardii Boiss. Orchis (L.) sp.

Briza sp., Lapsana sp.,

Fibigia (Medik.) sp.,

Salvia tomentosa,

Cerastium sp.

Valeriana sp.,

Phlomis grandiflora, Erysimum sp.

Juniperus foetidissima

Cotinus coggygria Geranium sp.,

Aubrieta pinardii

Cedrus libani, Juniperus excelsa, Juniperus foetidissima,

Lamium sp., Ornithogalum sp., Cerastium sp., Phlomis grandiflora, Muscari (Mill.) sp.

\section{Brachypodium sp. \\ Geranium sp. \\ Quercus coccifera,}

Geranium sp., Briza sp., Lapsana sp.

Cedrus libani, Juniperus foetidissima

Briza sp., Valeriana sp., Lamium sp.

Juniperus excelsa, Juniperus

foetidissima, Brachypodium sp.,

Geranium sp., Valeriana sp.,

Silene sp., Ornithogalum sp.

Quercus coccifera,

Juniperus excelsa, Lapsana sp., Alyssum sp., Aubrieta pinardii, Orchis sp., Lamium sp.

Briza sp., Lapsana sp., Fibigia sp., Salvia tomentosa, Cerastium sp., Silene (L.) sp.

Phlomis grandiflora, Erysimum sp., Valeriana sp.

Juniperus foetidissima,

Cotinus coggygria,

Geranium sp.,

Picnomon acarna (L.) Cass., Aubrieta pinardii,

Salvia tomentosa,

Allium (L.) sp.

Cedrus libani,

Juniperus excelsa,

Juniperus foetidissima, Cerastium sp., Phlomis grandiflora,

Lamium sp., Picnomon acarna,

Ornithogalum sp., Muscari sp., Salvia tomentosa, Allium sp. 


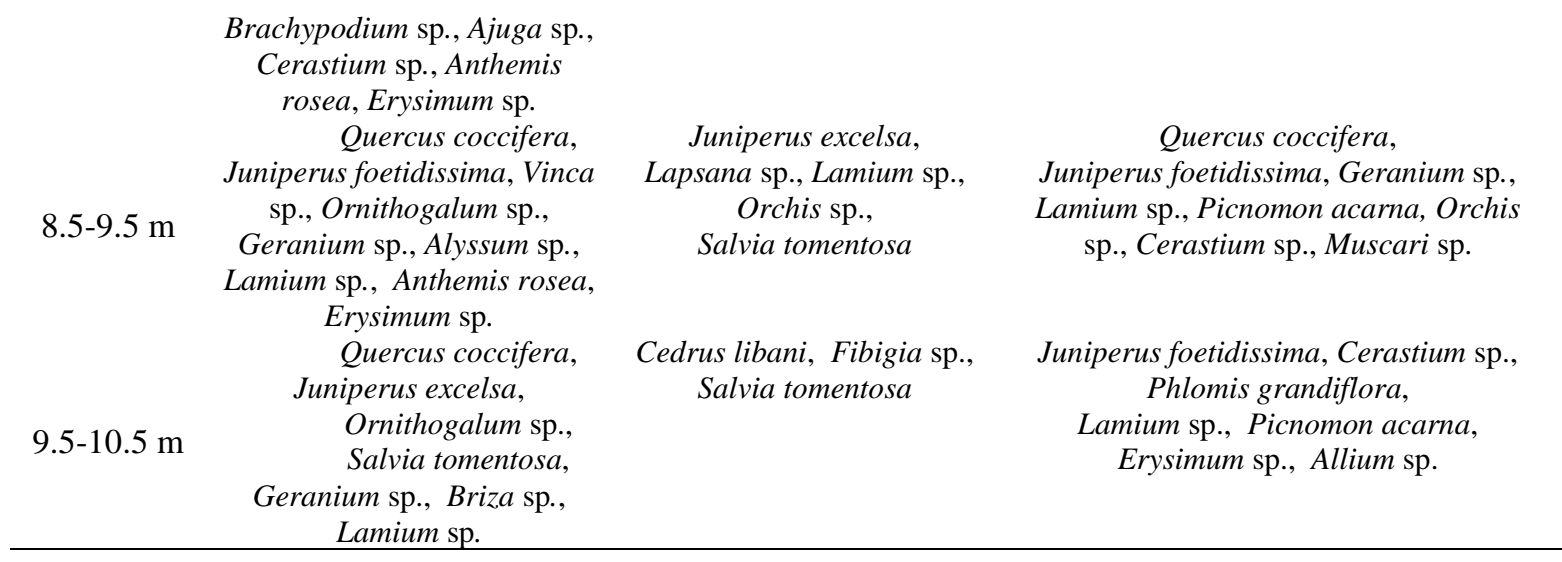

\section{Comparison of the Pollen Influxes}

According to the total pollen influx values obtained from the traps and the mosses for the years 20152017, the total pollen influxes obtained from the traps at all locations for 2015-2016 are higher than the total pollen influxes obtained from the mosses. In 2016-2017, the total pollen influxes of the moss are higher in only two sample areas (CJQ-1 and CJQ-4) (Figure 6).

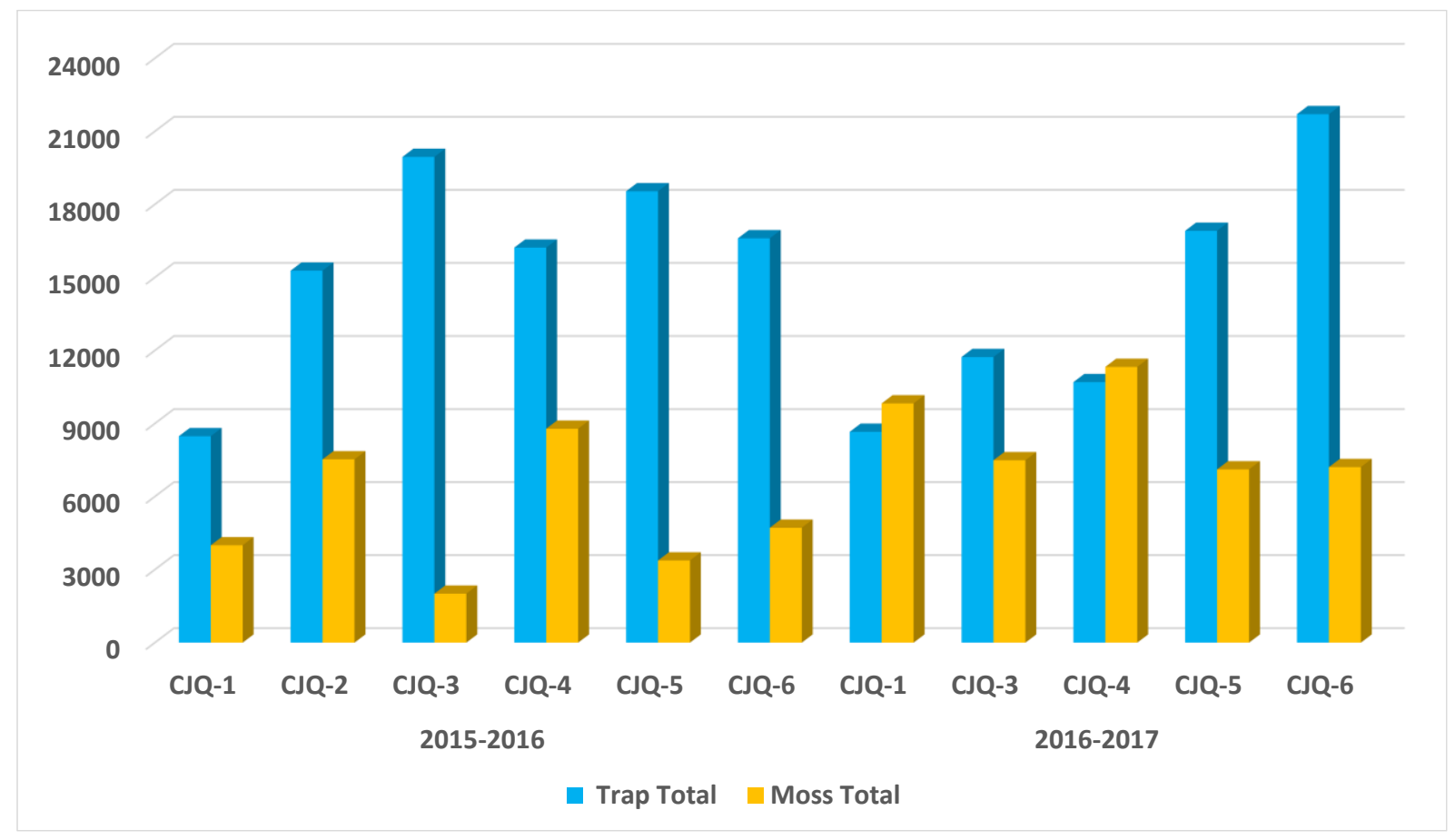

Figure 6. Total pollen influxes obtained from the traps and the mosses between 2015-2017 for all sample areas ( $\mathrm{cm}^{2} /$ year) at the location of Cedrus libani-Juniperus-Quercus (CJQ).

When the pollen data at the location of Cedrus libani-Juniperus-Quercus for 2015-2017 are compared in terms of both sample areas and annual total pollen influx, the majority of pollen influx belongs to AP taxa (Cedrus libani, Pinus sp., Quercus coccifera, Juniperus sp.) (Figure 6). In all sample areas (in the Tauber pollen traps, moss samples), the highest influx between the years 2015-2017 belongs to Cedrus libani. However, in the surface sediment sample obtained from Lake Avlan, the highest influx 
belongs to Pinus sp. Pollen influx values at the location of Cedrus libani-Juniperus-Quercus (CJQ-Y) increased in all sample areas in 2016-2017.

In the study area, the modern pollen percentage for the Tauber pollen traps, the moss samples, and the surface sediment sample was obtained for 2016-2017 (Figure 7). According to these data, the pollen percentage of herbaceous species (for the Tauber pollen traps, moss samples, surface sediment sample) was low at the CJQ location. Therefore, the ratio of woody species was stated. The taxa with the highest pollen percentage in the CJQ-1-T sample area are Cedrus libani (46.4\%), Juniperus sp. (16.8\%), Pinus sp. (15.1\%), and Quercus coccifera (8.1\%). The ratio of AP is $89.5 \%$, and the ratio of non-arboreal (NAP) is $10.5 \%$. In the CJQ-2-T sample area, the trap was damaged. The taxa with the highest ratio in the CJQ-3-T are Cedrus libani (41.9\%), Pinus sp. (20.4\%), Juniperus sp. (17.9\%), and Quercus coccifera $(12.6 \%)$. The ratio of AP is $94.1 \%$, and the ratio of NAP is $5.9 \%$. The taxa with the highest ratio in the CJQ-4-T sample area are Cedrus libani (42.2\%), Pinus sp. (20.4\%), Juniperus sp. (9.9\%), and Quercus coccifera (9.1\%). The ratio of AP is $85.5 \%$, and the ratio of NAP is $14.5 \%$. The taxa with the highest ratio in the CJQ-5-T are Cedrus libani (43.8\%), Pinus sp. (32\%), Juniperus sp. (9.9\%), and Quercus coccifera (8.7\%). The ratio of AP is $95.4 \%$, and the ratio of NAP is $4.6 \%$. The taxa with the highest ratio in the CJQ-6-T sample area are Cedrus libani (47\%), Pinus sp. (18\%), Juniperus sp. (17\%), and Quercus coccifera (8\%) (Figure 7). The ratio of AP is $91.1 \%$, and the ratio of NAP is $8.9 \%$ (Figure 8 ).

The taxa with the highest pollen percentage in the CJQ-1-Y sample area are Cedrus libani $(69.6 \%)$, Pinus sp. (13.3\%), Quercus coccifera (5.8\%), and Juniperus sp. (1.5\%). The ratio of AP is $94.2 \%$, and the ratio of NAP is $4.7 \%$. Since the trap was damaged in the CJQ-2-Y sample area, no analysis was performed. The taxa with the highest ratio in the CJQ-3-Y are Cedrus libani (58.9\%), Pinus sp. (19.1\%), Quercus coccifera (13.2\%), and Juniperus sp. (4.9\%). The ratio of AP is $96.2 \%$, and the ratio of NAP is 3.8\%. The taxa with the highest ratio in the CJQ-4-Y are Cedrus libani (43.8\%), Quercus coccifera (19.3\%), Pinus sp. (12.8), and Juniperus sp. (8\%). The ratio of AP is $84 \%$, and the ratio of NAP is $16 \%$. The taxa with the highest ratio in the CJQ-5-Y sample area are Cedrus libani (61.4\%), Quercus coccifera (15.9\%), Pinus sp. (10.8\%), and Juniperus sp. (3\%). The ratio of AP is $91.3 \%$, and the ratio of NAP is $8.7 \%$. The taxa with the highest ratio in the CJQ-6-Y are Cedrus libani (49\%), Quercus coccifera (18.3\%), Pinus sp. (15.8\%), and Juniperus sp. (5.5\%) (Figure 7). The ratio of AP is $88.8 \%$, and the ratio of NAP is $11.2 \%$ (Figure 8 ).

In the surface sediment sample obtained from Lake Avlan, taxa with the highest pollen percentage were Pinus sp. (54.2\%) and Cedrus libani (24.6\%). The pollen percentages of Quercus coccifera and Juniperus sp. were not found (Figure 7). The ratio of AP is $88.8 \%$, and the ratio of NAP is $11.2 \%$ (Figure 8).

When the modern pollen percentage obtained from the Tauber pollen traps, moss and surface sediment samples at the location of Cedrus libani-Juniperus sp.-Quercus sp. are evaluated (Figure 7 and 8), 78.8 to $96.2 \%$ of the pollen percentage distribution consists of four woody taxa (Cedrus libani, Juniperus sp. Pinus sp., and Quercus coccifera). 84 to $96.2 \%$ of the pollen percentage distribution in the samples of the Tauber pollen traps, mosses, and surface sediments consists of the AP ratio (Figure 7 and 8). 


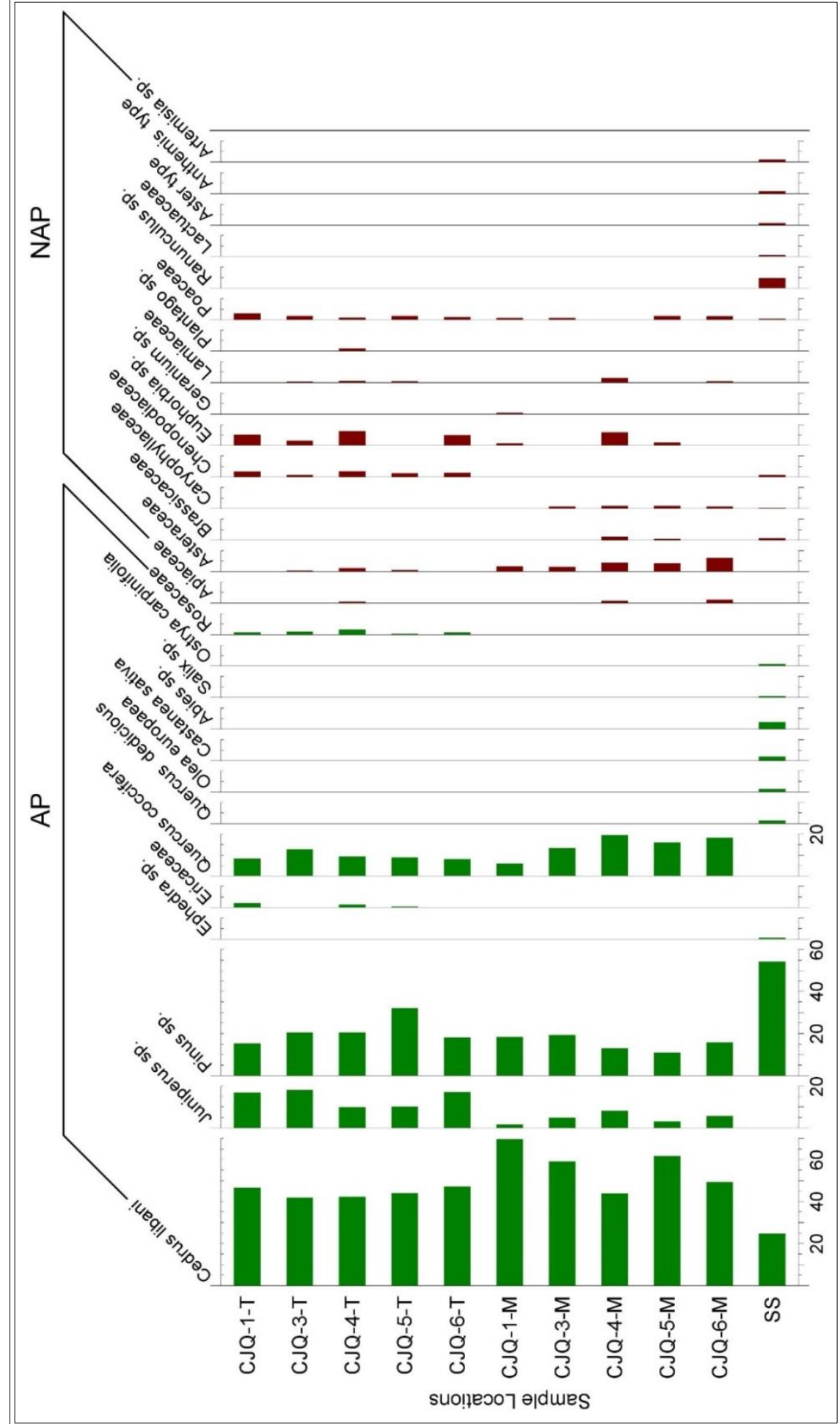

Figure 7. Pollen percentage obtained from the samples of Tauber pollen traps, mosses and surface sediment (for 2016-2017) at the location of Cedrus libani-Juniperus sp.-Quercus sp. (CJQ).

(CJQ-1-T, CJQ-3-T, CJQ-4-T, CJQ-5-T and CJQ-6-T belong to Tauber pollen traps, CJQ-1-M, CJQ-3-M, CJQ4-M, CJQ-5-M and CJQ-6-M belong to mosses, SS belongs to the surface sediment sample). 


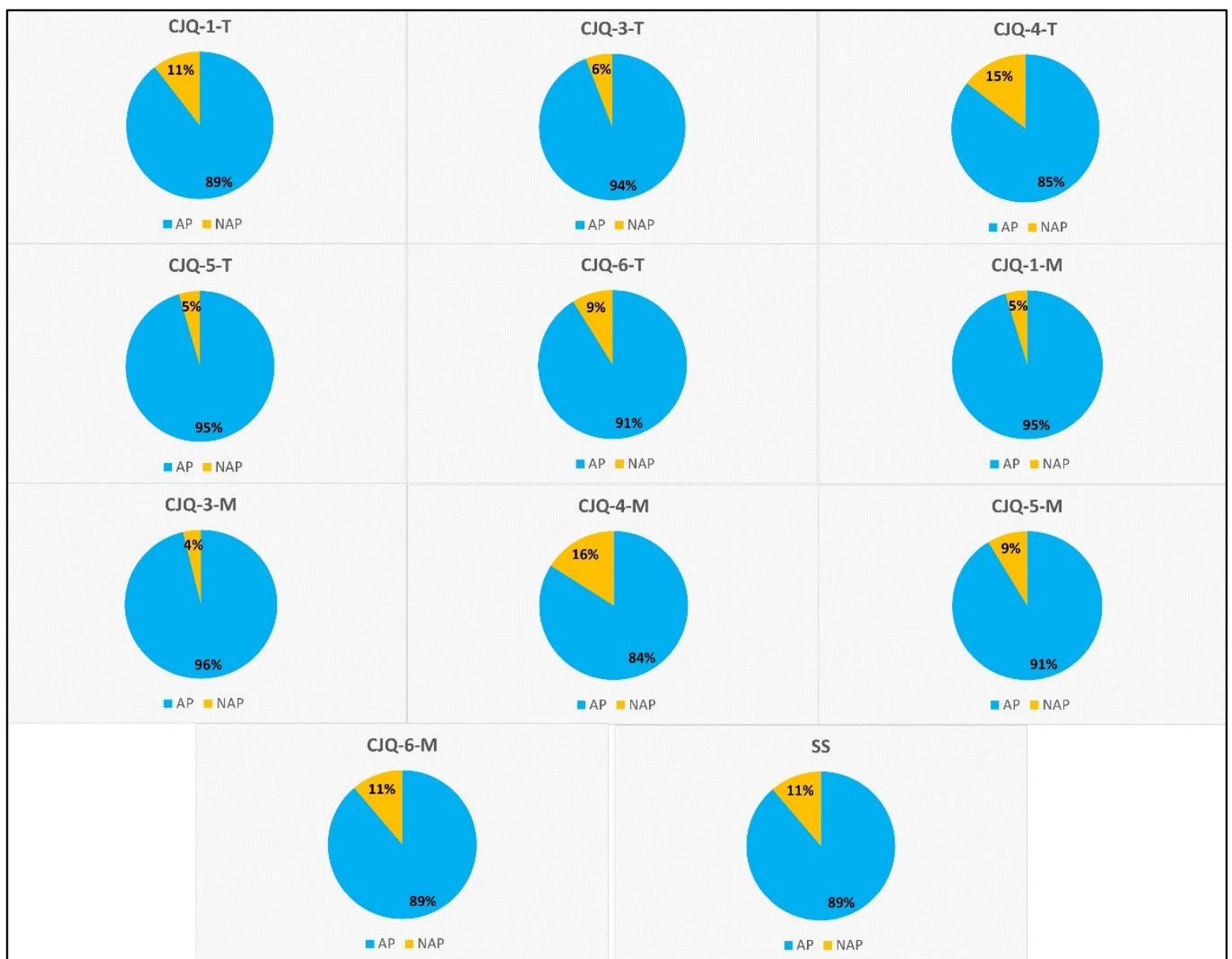

Figure 8. Comparison of the pollen percentages obtained from the samples of Tauber pollen traps, mosses and surface sediment (for 2016-2017) in terms of AP and NAP.

\section{Discussion and Conclusion}

Woody taxa (Cedrus libani, Juniperus, and Quercus coccifera) and herbaceous taxa (Euphorbia, Caryophyllaceae, Poaceae, Asteraceae, Lamiaceae, Brassicaceae, and Apiaceae), which have the highest pollen influx between the years 2015-2017 in the Tauber pollen traps and moss samples, are found in the vegetation. The modern pollen influxes obtained from this study reflect the vegetation. Although Pinus sp. is not found in the vegetation, it is among the taxa with the highest influx. While Pinus sp. produces a large amount of pollen, it can easily be carried by the wind at very long distances with the help of bubble vesicles (Faegri and Iversen 1989, Szczepanek et al. 2017). According to this information, the modern pollen influxes reflect the local vegetation structure, and they show that the transport of Pinus sp. to the field is quite important.

According to the modern pollen percentage values obtained in the Cedrus libani-Juniperus-Quercus forest, the majority of modern pollen percentage distribution (between $84 \%$ and $94 \%$ ) in the study area consists of AP taxa. Among these taxa, Cedrus libani, Pinus sp., Quercus coccifera, Juniperus sp. account for almost all of the AP percentage. Cedrus libani has a percentage of more than $41 \%$ in the modern pollen AP percentage obtained from the Tauber pollen traps and moss samples. However, the percentage of Cedrus libani decreased to $24.6 \%$ in the surface sediment sample obtained from Lake Avlan. Pinus sp., which has an average value of $18 \%$ in the Tauber pollen traps and moss samples, has a percentage of $54.2 \%$ in the surface sediment sample. In the study of Bottema and Woldring (1984) the percentage of Pinus pollen was higher than Cedrus pollen in the top zone of the pollen diagram obtained from Lake Avlan. As a result of this study, the pollen percentages obtained from the Tauber 
pollen traps, moss, and surface sediment samples were compared with the study of Bottema and Woldring (1984) the taxa with the highest woody pollen percentage were found to be the same (Cedrus, Pinus, Quercus, and Juniperus). In this context, by carrying out the modern pollen monitoring studies at different vegetation points, previously obtained fossil pollen diagrams have become more comfortable to interpret.

\section{Acknowledgement}

This study was supported by the project entitled "Determination of the Modern Pollen Distribution in the Forests of the Teke Peninsula and the Conditions of Microclimate" numbered 214O249 within the scope of TÜBİTAK 3501 program. We would like to thank Prof. Dr. Mustafa Kargığlu, a faculty member at the Department of Molecular Biology and Genetics, Faculty of Science and Literature, Afyon Kocatepe University for his help in collecting and identifying modern plant samples.

\section{References}

Bakker, J., Kaniewski, D., Verstraeten, G., Laet, V.D., Waelkens, M. (2011). Numerically derived evidence for late-Holocene climate change and its impact on human presence in the southwest Taurus Mountains, Turkey. The Holocene 22, 425-438.

Birks, H.J.B. (2013). Numerical Analysis Methods. In Encyclopedia of Quaternary Science" (Scott Elias, Cary Mock), Second Edition, Volome 3, Elsevier, pp. 821-830.

Bottema, S., Woldring, H. (1984). Late quaternary vegetation and climate of southwestern Turkey Part II. Palaeohistoria 26, 245-249.

Brewer, S., Guiot, J., Barboni, D. (2013). Use of Pollen as Climate Proxies. In Encyclopedia of Quaternary Science" (Scott Elias, Cary Mock), Second Edition, Volome 3, Elsevier, pp. 805-815.

Davis, M.B. (1968). Pollen grains in lake sediments: redeposition caused by seasonal water circulation. Science 162:796-799.

Davis, M.B., Brubaker, L.B. (1973). Differential sedimentation of pollen grains in lakes. Limnology and Oceanography 18:635-646.

Davis, M.B., Moeller, R.E., Ford, J. (1984). Sediment focusing and pollen influx. In: Haworth Y, Lund J.W.G (eds) Lake sediments and environmental history. University of Leicester Press, Leicester, pp. 261-293.

Doğan, M. (2017). Fosil ve Güncel Polen Analizleri Işı̆̆ında Mucur Çevresinin Geç Holosen Paleovejetasyonu. [Yayımlanmamış Yüksek Lisans Tezi] Süleyman Demirel Üniversitesi. Sosyal Bilimler Enstitüsü, Coğrafya Anabilim Dalı, Isparta.

Eastwood, W.J. (1997). The Palaeoecological Record of Holocene Environmental Change in Southwest Turkey. [PhD Thesis] University of Wales.

England, A. (2006). Late Holocene Palaeoecology Of Cappadocia (Central Turkey): An Investigation Of Annually Lamınated Sedıments From Nar Gölü Crater Lake. [PhD Thesis] University of Birmingham.

Faegri, K., Iversen, J. (1989). In K. Faegri, P. E. Kaland \& K. Krzywinski (Eds.), Textbook of pollen analysis (4th ed., pp. 236). Chichester: Wiley.

Fægri, K., Iversen. J. (1975). Textbook of Pollen Ana lysis. 3rd ed., New York. Hafner Press.

Glew, J.R. (1995). Conversion of shallow water gravity coring equipment for deep water Operation, Journal of Paleolimnology 14: 83-88.

Grimm, E. (2015). Tilia Software. Illinois State Museum, Springfield.

Herzschuh, U., Birks, H.J.B. (2010). Evaluating the indicator value of Tibetan pollen taxa for modern vegetation and climate. Review of Palaeobotany and Palynology 160: 197-208. 
Hicks, S. (1986). Modern Pollen Deposition Records from Kuusamo, Finland II. The Establishment of Pollen: Vegetation Analogues. Grana (25), pp. 183-204.

Hicks, S., Ammann, B., Latalowa, M., Pardoe, H., Tinsley, H. (1996). European Pollen Monitoring Programme: Project Description and Guidelines. University of Oulu, pp. 28.

Hicks, S., Hyvärinen, V.P. (1986). Sampling modern pollen deposition by means of, Tauber traps': some considerations. Pollen et Spores. 28: 219-242.

Kaniewski, D.L., De Laet, V., Paulissen, E., Waelkens, M. (2007). Long-term effects of human impact on mountainous ecosystems, western Taurus Mountains, Turkey. Journal of Biogeography, 1-23.

Karlığlu, N. (2011). Istranca ve Belgrad Ormanlarında Güncel Polen Dağılımının İncelenmesi. [Doktora Tezi] İstanbul Üniversitesi Fen Bilimleri Enstitüsü.

Karlığlu, N., Akkemik, Ü. (2012). İ.Ü. Orman Fakültesi Araştırma Ormanı'nda Eylül 2007-Ağustos 2009 Dönemi Güncel Polen Dağılımı, Journal of the Faculty of Forestry, Istanbul University, 62 (2), 145-158.

Karlıŏglu, N., Caner, H., Akkemik, Ü. (2014). Modern pollen distribution at Iğneada waterlogged forests between the periods September 2007-August 2009, Eurasian Journal of Forest Science, 2 (2), 7-17.

Karlığlu, N., Caner, H., Akkemik, Ü., Köse, N., Kındap, T. (2015). Modern Pollen Monitoring of Native Trees in Belgrad Forest, Istanbul (Northwestern Turkey), Comptes rendus de I'Académie bulgare de Sciences, 68 (1), $39-48$.

Moore, P.D., Webb, J.A., Collinson, M.E. (1991). Pollen Analysis. Blackwell, Oxford.

Müllenhoff, M., Hand, M., Knipping, M., Brückner, H. (2004). The evolution of Lake Bafa (Western Turkey)Sedimentological, microfaunal and palynological results, G. Schernewski und T. Dolch (Hrsg.): Geographie der Meere und Küsten Coastline Reports 1 (2004), ISSN 0928-2734, pp. 55-66.

Poska, A. (2013). Surface Samples and Trapping, In Encyclopedia of Quaternary Science (Scott Elias, Cary Mock), Second Edition, Elsevier, pp. 2908-2914.

Reille, M. (1995). Polen et Spores D’Europe Et D’Afrigue Du Nord, Supplement 1, Laboratoire De Botanique Palynologie Marselille-France.

Reille, M. (1998). Pollen et spores d'Europe et d'Afrique du Nord: supplement 2, Laboratoire d Botanique Historique et Palynologie. Marselille-France.

Reille, M. (1999). Pollen et spores d'Europe et d'Afrique du Nord, 2 Edn., Laboratoire de Botanique Historique et alynologie. Marselille-France.

Roberts, N. (2014). The Holocene an Environmental History (3nd edition).

Seppa, H. (2013). Pollen Analysis, Principles. In Encyclopedia of QuaternaryScience" (Scott Elias, Cary Mock), Second Edition, Volome 3, Elsevier, pp. 794-804.

Shumilovskikh, L.S., Seeliger, M., Feuser, S., Novenko, E., Schlütz, F., Pint, A., Pirson, F., Brückner, H. (2016). The harbour of Elaia: A palynological archive for human environmental interactions during the last 7500 years. Quaternary Science Reviews 149:167-187.

Soepboer, W., Sugita, S., Lotter, AF. (2010). Regional vegetation-cover changes on the Swiss Plateau during the past two millennia: A pollen-based reconstruction using the REVEALS model. Quaternary Science Reviews 29: $472-483$.

Sugita, S. (1994). Pollen representation of vegetation in quaternary sediments: theory and method in patchy vegetation. Journal of Ecology 82:881-897.

Sugita, S. (1993). A model of pollen source area for an entire lake surface. Quaternary Research 39:239-244. 
Sullivan, D.G. (1989). Human-induced vegetation change in western Turkey: Pollen evidence from central Lydia. [PhD Thesis] University of California, Berkeley.

Szczepanek, K., Myszkowska, D., Worobiec, E., Piotrowicz, K., Ziemianin, M., Bielec-Bakowska, Z. (2017). The long-range transport of Pinaceae pollen: an example in Krako'w (southern Poland), Aerobiologia 33:109125.

Şenkul, Ç., Doğan, M. (2018). Fosil ve güncel polen analizleri 1şığında Mucur Obruk Gölü çevresinin Paloevejetasyon değişimleri. Türk Coğrafya Dergisi (70), 19-28. DOI:19.17211/tcd.342955.

Şenkul, Ç., Karlığlu Kılıç, N., Kargıŏlu, M. (2018a). Teke Yarımadası Ormanlarında Güncel Polen Dağılımının ve Mikro İklim Koşullarının Belirlenmesi, TÜBİTAK Proje No: 214O249, Isparta.

Şenkul, Ç., Karlıŏlu Kılıç, N., Kargıŏ̆lu, M., Kulakoğlu, F. (2018b). Kültepe (Kayseri) Çevresinin Fosil ve Güncel Polen Analizleri Işı̆̆ında Holosen Ortamsal Değişimi, TÜBİTAK Proje No: 114Y578, Isparta.

Tauber, H. (1974). A static non-overload pollen collector. New Phytologist. 73: 359-369.

van Zeist, W., Woldring, H., Stapert, D. (1975). Late quaternary vegetation and climate of southwestern Turkey. Palaeohistoria 17, 55-143.

Vermoere, M., Degryse, P., Vanhecke, L., Muchez, Ph., Paulissen, E., Smets, E., Waelkens, M. (1999). Pollen analysis of two travertine sections in Basköy (southwestern Turkey): implications for environmental conditions during the early Holocene. Review of Palaeobotany and Palynology (105), 93-110.

Vermoere, M., Bottema, S., Vanhecke, L., Waelkens, M., Paulissen, E., Smets, E. (2002). Palynological evidence for late-Holocene human occupation recorded in two wetlands in SW Turkey. The Holocene (12), 569584.

Wang, Y., Herzschuh, U., Shumilovskikh, L.S., Mischke, S., Birks, H.J.B., Wischnewski, J., Böhner, J., Schlütz, F., Lehmkuhl, F., Diekmann, B., Wünnemann, B., Zhang, C. (2014). Quantitative reconstruction of precipitation changes on the NE Tibetan Plateau since the Last Glacial Maximum extending the concept of pollen source area to pollen-based climate reconstructions from large lakes. Clim Past 10:21-39.

Wilmshurst, J.M., McGlone, M.S. (2005). Origin of pollen and spores in surface lake sediments: comparison of modern palynomorph assemblages in moss cushions, surface soils and surface lake sediments. Review of Palaeobotany and Palynology 136:1-15.

https://www.paldat.org/ (Visited on date: 30.04.2017)

https://www.polleninfo.org (Visited on date: 01.05.2017)

Submitted: 12.12 .2018

Accepted: 27.12.2018 